\title{
The Prospect Analysis of Sino-US Manufacturing Trade Friction Based on the Perspective of Evolutionary Game
}

\author{
Jianjun Zhou ${ }^{1}$, Jing Yang $^{2}$, Xiaocheng Huang ${ }^{{ }^{*}}$ \\ ${ }^{1}$ School of economics, Central University of Finance and Economics, Beijing, Beijing, China \\ ${ }^{2}$ School of Information and Electronic Engineering, Liming vocational university, Quanzhou, Fujian,
}

China

*Corresponding Author.

\begin{abstract}
The Sino-US trade friction since 2018 is an important turning point in trade relations between these two countries. As the world's two major manufacturing powers, the friction will have a profound impact on the world. This article sorts out the comparison of economic and trade strength between these two countries in the past ten years, the dependence of import and export, and the changes in trade structure. Then we construct a dynamic evolutionary model of the strategic choices of these two countries in trade friction from the perspective of evolutionary game. Finally, we analyze the stability of the equilibrium point of the evolutionary game by copying the dynamic equation. The results show that when at least one of these two countries has a cooperative benefit less than the speculative benefits brought about by competition, (competition, competition) is the only evolutionary stable strategy combination, and both of them will adopt competitive measures. The prerequisite for the combination of (cooperation, cooperation) strategies adopted by these two countries are that the net benefits obtained by the two countries' cooperation strategies are greater than the speculative benefits obtained when one side chooses to cooperate and the other side adopts competitive strategy. The probability that two countries choose cooperation strategy is directly proportional to benefits brought about by cooperation and inversely proportional to the cost of cooperation, the loss of sticking to the cooperation strategy, and the speculative benefits of abandoning cooperation. The trade policies of these two countries cannot be achieved overnight, but can gradually tend to be stable and balanced through mutual imitation and learning.
\end{abstract}

Keywords: Sino-US trade, Sino-US Manufacturing, trade friction, evolutionary game, strategy choice

\section{Introduction}

Since the establishment of diplomatic relations between China and the USA in 1979, the relations between these two countries have experienced ups and downs, showing a trend of an upward spiral. After the honeymoon period in the 1980s and the turbulent period in the 1990s, Sino-US relations have entered a relatively stable state in the 21 st century. At this stage, due to the gap in economic strength between China and the USA and the complementarity of trade, the economic and trade relations between the two countries have been continuously strengthened, and bilateral trade between them has entered the fast lane. Since 2011, as the economic power gap between China and the USA has narrowed, the USA has begun to face China's challenges in comprehensive national strength, especially in economic and trade fields. And then it has proposed a strategy of returning to the Asia-Pacific region and shifting its strategic focus to these regions. In this stage, Competition and cooperation coexist in the Sino-US economic and trade area.

After President Trump took office, he has continuously provoked trade friction against China and regarded China as a direct strategic competitor. As a result, Sino-US economic and trade relations have deteriorated sharply. On March 23, 2018, the Trump administration of the USA imposed tariffs of $25 \%$ and $10 \%$ on steel and aluminum products from China. At the same time, China took measures to counter the US's imposing tariffs. Starting from

ISSN: 0010-8189

(c) CONVERTER 2020

www.converter-magazine.info 
Volume 2021, No. 3

January 1, 2018, 15\% and 25\% tariffs were imposed on approximately $\$ 3$ billion imports from the USA, which opened the prelude to trade friction between China and the USA. Since then, the tariff wars and trade friction between these two countries have become fiercer. The range of tariff spreads from some trade products to all products, and the rate of tariff has continued to subjoin. The outbreak of the Sino-US trade war marked a major change in Sino-US relations, and it began to change from a situation of coexistence of competition and cooperation to strategic competition. Based on the comparison of the economic and trade strength between China and the USA and changes in the trade structure, this paper constructs a selection model of strategic behavior between China and the USA in trade friction from the perspective of evolutionary games, as well as the evolutionary path of strategic equilibrium in dynamic games. On this basis, we analyze the development trend and influencing conditions of Sino-US trade friction.

\section{Literature Review of Sino-US Trade Friction}

With China's accession to the WTO and its in-depth participation in international division of cooperation, it faces more external uncertainties, which makes China's international trade friction continue to rise. Liu (2004) pointed out that in the process of China's economic rise, economic and trade friction are inevitable due to the comprehensive influence of ideological differences, trade protectionism, "China threat theory" and other external factors [1]. Pei (2005) pointed out that trade friction is a major challenge for China, and it is necessary to make an in-depth study of the deep contradictory restrictive factors in China's trade development [2]. Wang (2009) believes that China's current trade friction have a certain degree of objective inevitability. China will inevitably change the international division of cooperation and the distribution of benefits in the process of becoming a major economic and trade country, which will bring conflicts to vested interests within the existing international system [3]. Huang (2019) believes that the essence of trade friction is the conflict of comprehensive interests such as economy and politics conflicts between vested interests and emerging powers that later catch up [4].

At present, relevant research mainly focus on exploring causes and evolution of Sino-US trade friction, evaluating the impact of Sino-US trade friction, the future trends and countermeasures of Sino-US trade friction. For the causes of Sino-US trade friction, from the perspective of national development strategies, Chen (2018) pointed out that the essence of trade wars is the strategic competition and conflict between conservative and emerging powers under the conditions of economic globalization [5]. Liu (2018) thinks that the continuous escalation of Sino-US trade friction and the outbreak of the trade war are direct products of the USA government's changes in its trade policy towards China under the guiding concept of "American interests first" [6]. Wu (2019) believes that the Trump administration seeks to decouple from China, shifting economic and trade relations from the coexistence of cooperation and competition to competition, which has caused trade friction to intensify [7]. In addition, there are scholars discussing the causes of Sino-US trade friction from a political and economic perspective. Li (2019) believes that the negative expectations of trade for China are the main reason for the USA to launch a trade war toward China. The huge trade deficit, domestic conservative atmosphere in the USA, cognitive bias for the Chinese system are endogenous factors leading to negative expectations [8]. Li (2019) pointed out that the deterioration of the USA trade deficit caused by Trump's tax cuts is an important reason for the escalation of trade contradiction [9]. Yang (2018) pointed out that the political lobbying of the USA interest groups is the main factor that triggers the USA trade friction with China [10]. Wang (2018) thinks that the USA believes that China is not a market-leading economy country, and it has invisible barriers, forced technology transfer, and market distortions caused by government intervention. The USA used them as reasons to launch a trade war against China [11].

Regarding the impact of the Sino-US trade war, most scholars use different methods to assess the impact of trade friction. Waugh (2010) pointed out the trade friction between poor and rich countries is asymmetric in the system, and poor countries face higher trade friction costs [12]. Li (2018) used a general equilibrium model and set up six scenarios to evaluate the impact of trade friction. They found that trade friction was the result of a lose-lose situation and China's damage was even greater [13]. Amiti (2019) assessed the influence of trade friction on the USA economy and believes that the increase in tariffs on intermediate and final products will be passed on to the

ISSN: 0010-8189

(c) CONVERTER 2020

www.converter-magazine.info 
domestic prices of imported goods, thereby reducing the real national income of the USA [14]. Sheng (2019) believes that the escalating trade conflict between China and the USA has increasingly hit the prospects of the world economy, further worsening the USA current account deficit and weakening its comparative advantage [15]. Sachs (2019) also pointed out that the tough attitude adopted through trade protectionist trade policies and radical technology policies will have serious consequences, hinder the recovery and growth of the world economy, and bring serious risks to the economic development prospects of China and the USA [16]. From previous studies, we can know it is widely believed that trade friction will have an adverse effect on both China and the USA, resulting in a lose-lose situation, and China will suffer even greater losses.

For the future trend of the Sino-US trade friction and the countermeasures, most scholars believe that the Sino-US trade friction is a long-term national trade and even development strategy competition. Hong (2019) pointed out that the Sino-US trade conflict is a struggle between the two countries' trade interests, technological catch-up, global leadership, and other development problems. It will require extremely high political wisdom to manage this long-term and difficult conflict [17]. Luo (2019) believes that Sino-US trade friction will show normalization, complexity, and long-term characteristics, and it will be difficult to achieve fair, reciprocal, and balanced bilateral trade relations in the short term [18]. Chong (2019) believes that the fundamental contradiction between China and the USA cannot be easily resolved, so he is pessimistic about the complete resolution of the Sino-US trade dispute [19]. Different scholars have studied the countermeasures to the Sino-US trade friction from various angles. Pei (2019) pointed out that China's trade needs to transform the old and new kinetic energy, cultivate new forms of trade, and then form new advantages in China's trade international competition [20]. Feng (2018) believes that free trade agreements are significantly helpful to reduce trade friction with partner countries, and it is necessary to speed up the construction of free trade zones and bilateral investment negotiations with key trading partners [21]. $\mathrm{Yu}$ (2019) pointed out that a wise way for China to resolve the Sino-US trade friction is to increase imports from the USA, urging it to low restrictions on high-tech exports toward China and remove bilateral trade barriers between them [22].

At the same time, some scholars have analyzed the Sino-US trade friction from the perspective of the game. Li (2018) established a static game based on rational participants and then studied the formation mechanism of trade friction. She believed that Sino-US cooperation can achieve an equilibrium of advantages, but Sino-US trade friction will continue or even be more complicated [23]. Wang (2019) analyzes from the perspective of game theory and believes that the Sino-US trade war will be long-term, arduous, and protracted [24]. From the perspective of multiple game, Xie (2019) pointed out that the competitive relationship between China and the USA will gradually replace economic dependence. Curbing China's development, and preventing China's catching up has become realistic demands and established strategic targets for the USA [25].

Judging from past research literature, most scholars analyze the causes of Sino-US trade friction from traditional trade theories. They also analyze the impact and consequences of Sino-US trade friction and predict the trend of trade friction from multiple angles. Related research has a very strict and completely rational premise. The trade friction between China and the USA is a long-term struggle, various sudden factors occur frequently, so it is quite difficult to achieve a completely rational theoretical assumption. Secondly, there is a state of incomplete information and a huge gap in ideology and interest demands between China and the USA. Therefore, it is difficult to accurately understand each other's strategic intentions in exchanges and negotiations. Finally, the complexity of trade policy negotiations makes it impossible for both parties to make the best strategy choices at once. They can only go through repeated trade negotiations, dialogue and competition, observe each other's reactions and calculate the benefits and losses of both parties, then continue to learn and adjust from it, and finally stabilize in the optimal strategy combination. Therefore, we first reviews changes in comparison of economic and trade strength between China and the USA in the past ten years and the differences in the trade field. Then we analyze the process of Sino-US trade friction, and constructs an Evolutionary Stable Strategy (ESS), and Replicator Dynamics to discuss the strategic choice and stabilization strategy in the current stage of trade friction between China and the USA, then

ISSN: 0010-8189

(c) CONVERTER 2020

www.converter-magazine.info 
get the most balanced point. We can provide a clear idea for the theoretical and empirical research of Sino-US trade friction.

\section{The Evolution and Development of Sino-US Economic and Trade Relations}

\subsection{Comparison of China-US economic and trade strength}

With the continuous development of China's economy, its status and importance in the world economic and trade structure is progressive, and the comparison of strength between China and the USA has undergone extremely obvious changes. Figure 1 reflects changes in the world from 2001 to 2019. It can be seen that the proportion of Sino-US GDP in the world is a trade-off relationship. The USA has gradually decreased from $31.70 \%$ in 2001 to $24.42 \%$ in 2019 , but China has steadily increased from $4.01 \%$ in 2001 to $16.34 \%$ in 2019 . The gap between China and the USA in the proportion of the world economy has gradually reduced from $27.69 \%$ to $8.08 \%$. The trade gap is larger than the reduction in the economic gap. In 2001, China's total trade accounted for only $4.10 \%$ of the world's total trade, while the US accounted for $15.05 \%$. China's trade share increased while the USA's share decreased. In 2012, China's trade share in the world surpassed the USA for the first time. By 2019, China's trade share was $12.07 \%$, while the US's trade share was $11.13 \%$. A stalemate in the Sino-US trade and the gap between them is being very small. From the perspective of the economic and trade ratio, we can see that China's total economic volume in 2019 accounted for about $66.94 \%$ of the USA, and the total trade volume was 1.09 time of the USA. In the economic field, the USA still occupies a relatively obvious advantage, but in the field of trade, a more obvious "G2" pattern has been formed. As the USA strategic focus shifts to the Asia-Pacific region, the USA has gradually shifted from cooperative to competitive relationship with China, and conflicts of interest between the two countries have gradually emerged. The friction between the two countries in the trade field in 2018 is a key signal which suggests the relationship is changed to competition. It is the beginning of a strategic game between the USA as a conservative power and China as an emerging power, and that will make a profound impact on the future economic development of the two countries even on the international economic and trade pattern.

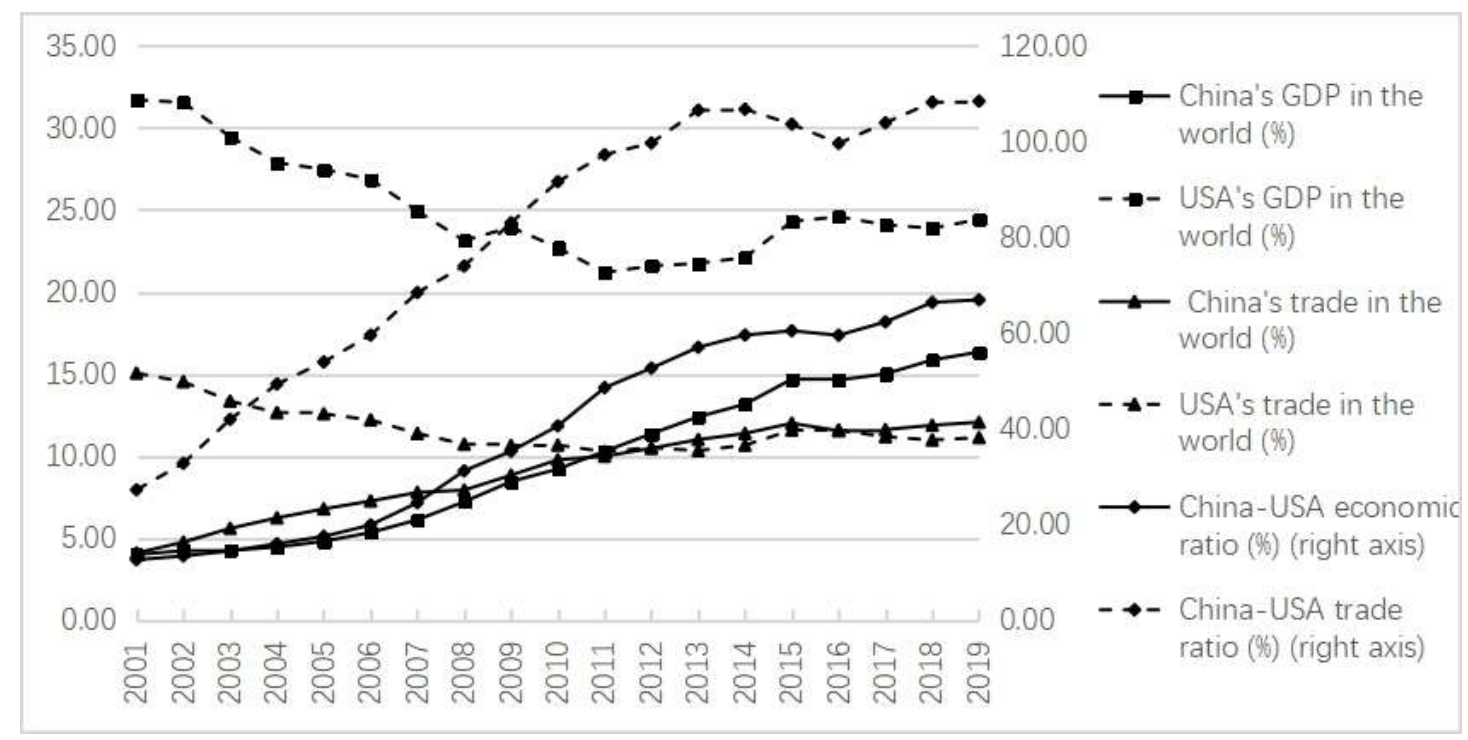

Fig 1 Changes in the economic and trade strength of China and the USA from 2001 to 2019 Data source: World Bank database and UN comrade database.

3.2 Sino-US import and export trade relations

As the world's major trading nations, China and the USA also occupy a very important position in each other's trade structure. As shown in Figure 2, China's exports to the USA accounted for $20.43 \%$ of its total exports in 2001. Among China's total imports, imports from the USA accounted for approximately $10.46 \%$. Correspondingly,

ISSN: 0010-8189

(C) CONVERTER 2020

www.converter-magazine.info 
China's share of total USA imports was approximately $8.96 \%$, while exports to China only accounted for $2.63 \%$ of total USA exports. China's exports and imports depended heavily on the USA, while China does not account for a high proportion of the USA import and export trade structure. Since China's accession to the WTO, its economic and trade strength has grown. And the USA's share in China's trade structure has been on a downward trend, while China's share in the USA's import and export trade structure has continued to increase. China's share in the USA's import structure has gradually increased from $8.96 \%$ in 2001 to $18.40 \%$ in 2019 , and the share of exports has increased from $2.63 \%$ in 2001 to $6.48 \%$ in 2019 . China's trade influence on the USA has greatly increased. Before the 2008 global economic crisis, the USA's trade influence on China was greater than China's trade influence on the USA. After that, the influence of the two sides changed.

In addition, the trade balance between China and the USA can also be seen in Figure 2. According to Chinese statistics, China's trade surplus with the USA in 2001 was 21.8 billion dollars. According to USA statistics, the USA trade deficit with China in 2001 was 83.1 billion dollars, and there was a divergence of about 54.9 billion dollars in the trade balance. And with the expansion of the scale of bilateral trade, the trade balance between the two countries is also increasing, but China's trade surplus is always larger than the US trade deficit with China. In 2019, the difference in the trade balance was 119.5 billion dollars. It can be seen from the figure that the difference in trade balance has been relatively stable in recent years, maintaining around 120 billion U.S. dollars. The differences between the two sides on the trade balance are mainly caused by the two methods of trade statistics. In China's trade statistics method, the identification of origin is relatively loose. China uses global accumulation, while the USA uses percentage standards, thus exaggerating China's trade surplus, which has become an important factor of Sino-US trade friction and the USA imposing tariffs on China.

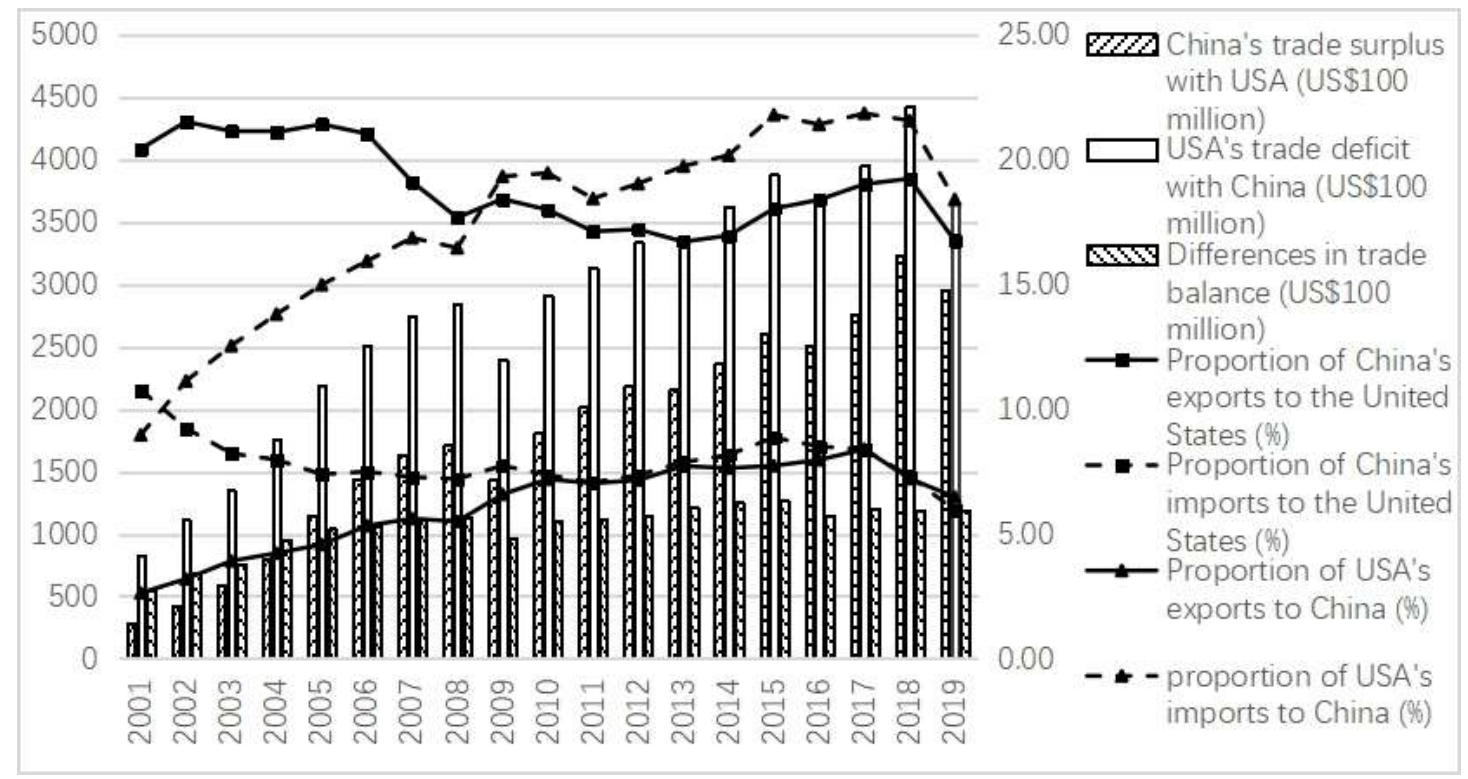

Fig 2 Changes in proportion and balance of China-USA import and export from 2001 to 2019 Data source: World Bank database and UN comrade database.

3.3 Sino-US export structure

Table 1 reflects the structural distribution of China and the USA's exports to each other from 2001 to 2019. As can be seen from the table, the sum of top ten chapters accounted for about three-quarters of the total exports, and export structure was relatively concentrated. From the perspective of China's export structure to the USA, HS84 and HS 85 have accounted for more than $45 \%$ of China's exports to the USA since 2007. The main export products are boiler machines, mechanical products and their parts, electromechanical, electrical equipment and their parts.

ISSN: 0010-8189

(c) CONVERTER 2020

www.converter-magazine.info 
As a major manufacturing country, China continues to have a quite strong industrial competitiveness against the USA in the low- and medium-end manufacturing fields such as machinery and electrical appliances. And it occupies an important position and role in the export trade to the USA. In the USA exports' structure to China, the total proportion of the top three export chapters has dropped from more than $50 \%$ in 2001 to about one-third since 2013. Compared with China, the USA export's structure is more scattered. The top three exports to China are HS84, HS85, HS88. In addition to HS84 and HS85 manufacturing products, there are also HS87, HS88 vehicles and aviation equipment, which represent high-end manufacturing.

In the structure of Sino-US export trade, China's exports to the USA are more concentrated in the HS85 and HS84, which have greater overlap with the USA's export structure to China. It can be seen that China and the USA are relatively competitive in the manufacturing sector, and manufacturing exports account for a large proportion of China's exports to the USA. The USA has started a tariff war against China's manufacturing industry in order to promote its reindustrialization strategy, allowing manufacturing to return to the USA, encouraging the growth of non-agricultural employment, and at the same time cracking down on China's trade and economy. As manufacturing occupies a large proportion of China's export structure, therefore, the trade war launched by the USA against China is highly targeted and lethal. And it will have a serious adverse effect on China's export trade.

Table 1 The top ten commodity export structures in China-USA from 2001 to 2019

\begin{tabular}{|c|c|c|c|c|c|c|c|c|c|c|c|c|}
\hline \multirow{2}{*}{ country } & \multicolumn{2}{|c|}{2001} & \multicolumn{2}{|c|}{2007} & \multicolumn{2}{|c|}{2013} & \multicolumn{2}{|c|}{2017} & \multicolumn{2}{|c|}{2018} & \multicolumn{2}{|c|}{2019} \\
\hline & Chapt & $(\%$ & Chapt & $(\%$ & Chapt & $(\%$ & Chapt & $(\%$ & Chapt & $(\%$ & Chapt & $(\%$ \\
\hline \multirow{11}{*}{$\begin{array}{c}\text { Export } \\
\text { structure: } \\
\text { China-U } \\
\text { SA }\end{array}$} & HS85 & 19.59 & HS85 & 24.03 & HS84 & 23.48 & HS85 & 24.86 & HS85 & 24.91 & HS85 & 24.81 \\
\hline & HS84 & 13.50 & HS84 & 22.25 & HS85 & 22.46 & HS84 & 21.32 & HS84 & 21.47 & HS84 & 20.79 \\
\hline & HS64 & 9.28 & HS94 & 5.89 & HS94 & 6.26 & HS94 & 6.80 & HS94 & 6.96 & HS94 & 6.57 \\
\hline & HS95 & 7.76 & HS95 & 4.55 & HS61 & 4.01 & HS95 & 4.33 & HS95 & 4.05 & HS95 & 4.79 \\
\hline & HS94 & 6.23 & HS62 & 3.81 & HS62 & 3.63 & HS61 & 3.72 & HS39 & 3.85 & HS61 & 4.26 \\
\hline & HS39 & 4.03 & HS73 & 3.78 & HS64 & 3.60 & HS39 & 3.57 & HS87 & 3.77 & HS39 & 4.06 \\
\hline & HS62 & 3.92 & HS64 & 3.54 & HS95 & 3.49 & HS87 & 3.52 & HS61 & 3.68 & HS87 & 3.48 \\
\hline & HS42 & 3.66 & HS61 & 3.36 & HS39 & 3.31 & HS62 & 3.27 & HS62 & 3.03 & HS62 & 3.27 \\
\hline & HS90 & 3.05 & HS87 & 2.85 & HS87 & 2.83 & HS64 & 2.79 & HS64 & 2.53 & HS64 & 2.81 \\
\hline & HS73 & 2.99 & HS39 & 2.60 & HS90 & 2.34 & HS73 & 2.37 & HS73 & 2.47 & HS73 & 2.39 \\
\hline & others & 25.97 & others & 23.33 & others & 24.59 & others & 23.46 & others & 23.27 & others & 22.77 \\
\hline \multirow{11}{*}{$\begin{array}{c}\text { Export } \\
\text { structure: } \\
\text { USA-Chi } \\
\text { na }\end{array}$} & HS84 & 21.13 & HS85 & 16.35 & HS12 & 11.25 & HS88 & 12.53 & HS88 & 15.17 & HS85 & 13.51 \\
\hline & HS85 & 17.89 & HS84 & 13.58 & HS88 & 10.34 & HS84 & 9.93 & HS84 & 11.82 & HS84 & 12.04 \\
\hline & HS88 & 12.76 & HS88 & 11.03 & HS84 & 10.02 & HS87 & 9.91 & HS85 & 10.72 & HS88 & 10.98 \\
\hline & HS90 & 6.51 & HS12 & 6.41 & HS85 & 9.35 & HS12 & 9.90 & HS90 & 8.15 & HS90 & 9.06 \\
\hline & HS12 & 5.38 & HS39 & 5.52 & HS87 & 8.49 & HS85 & 9.34 & HS87 & 7.81 & HS87 & 8.16 \\
\hline & HS39 & 4.37 & HS90 & 5.08 & HS90 & 6.30 & HS90 & 6.79 & HS27 & 7.03 & HS12 & 6.68 \\
\hline & HS72 & 2.38 & HS72 & 3.41 & HS39 & 3.90 & HS27 & 6.55 & HS39 & 4.75 & HS39 & 4.83 \\
\hline & HS41 & 2.25 & HS74 & 3.32 & HS47 & 2.96 & HS39 & 4.36 & HS12 & 3.05 & HS27 & 4.42 \\
\hline & HS31 & 2.19 & HS29 & 3.22 & HS74 & 2.85 & HS47 & 2.59 & HS47 & 2.42 & HS30 & 3.78 \\
\hline & HS29 & 2.08 & HS47 & 3.15 & HS29 & 2.55 & HS44 & 2.46 & HS44 & 2.38 & HS38 & 2.45 \\
\hline & others & 23.06 & others & 28.94 & others & 31.98 & others & 25.63 & others & 26.70 & others & 24.10 \\
\hline
\end{tabular}

Data source: United Nations UN Comtrade database.

\section{The Evolutionary Game Analysis of The Sino-US Trade War}

4.1 The process of Sino-US trade friction

ISSN: 0010-8189

(c) CONVERTER 2020

www.converter-magazine.info 
Volume 2021, No. 3

Until October 2019, China and the USA have both imposed additional tariffs and other applicable trade sanctions against each other. Among them, the USA tariff increase is divided into four parts, which are tariff on steel and aluminum products, 200 billion dollars, 250 billion dollars, and 300 billion dollars; And China's tariff increase is divided into 5 parts, which are 3 billion dollars, 34+16 billion dollars, 60 billion dollars, 75 billion dollars, the tariff on American cars and auto parts.

Table 2 The history of China and the USA imposing tariffs on each other

\begin{tabular}{|c|c|}
\hline $\begin{array}{l}\text { Several measures taken by the USA to impose tariffs } \\
\text { on China }\end{array}$ & $\begin{array}{l}\text { Several measures taken by China to impose tariffs on } \\
\text { the USA }\end{array}$ \\
\hline $\begin{array}{c}\text { 1. On March } 18,2018 \text {, the USA announced that it } \\
\text { would impose } 25 \% \text { and } 10 \% \text { tariffs on steel and } \\
\text { aluminum products imported from China on March } \\
23,2018 \text {. }\end{array}$ & $\begin{array}{l}\text { 1. On April 1, 2018, China announced that starting } \\
\text { from April } 2 \text { it will impose } 15 \% \text { and } 25 \% \text { tariffs on } \\
\text { approximately } \$ 3 \text { billion of goods imported from the } \\
\text { USA. }\end{array}$ \\
\hline $\begin{array}{l}\text { 2. On May } 10,2019 \text {, the USA announced that the } \\
\text { additional tariff rate on } \$ 200 \text { billion imported from } \\
\text { China would be increased from } 10 \% \text { to } 25 \% \text {. }\end{array}$ & $\begin{array}{l}\text { 2. On July } 7,2018 \text {, China imposed an additional } 25 \% \\
\text { tariff on } \$ 34 \text { billion imported goods from the USA, } \\
\text { and it began to take effect. }\end{array}$ \\
\hline $\begin{array}{l}\text { 3. On August } 24,2019 \text {, the USA announced that the } \\
\text { tariff rate on } \$ 300 \text { billion imported from China } \\
\text { would be raised to } 15 \% \text {. }\end{array}$ & $\begin{array}{c}\text { 3. On August 23, 2018, China's additional 25\% tariff } \\
\text { imposed on \$16 billion imports from the USA took } \\
\text { effect. }\end{array}$ \\
\hline $\begin{array}{l}\text { 4. On September 1, 2019, the USA announced a } 10 \% \\
\text { tariff on Chinese products priced at approximately } \\
\qquad 300 \text { billion. }\end{array}$ & $\begin{array}{l}\text { 4.2018.8.3 China announced that it will impose } \\
\text { additional tariffs of } 25 \%, 20 \%, 10 \% \text { and } 5 \% \text { on } \\
\text { approximately US } \$ 60 \text { billion imported from the } \\
\text { USA. }\end{array}$ \\
\hline $\begin{array}{c}\text { 5. On September } 12,2019 \text {, the USA announced that } \\
\text { the plan to impose } 30 \% \text { tariffs on } 250 \text { billion dollars } \\
\text { of goods imported from China will be implemented } \\
\text { on October } 15,2019 .\end{array}$ & $\begin{array}{l}\text { 5. On May 13, 2019, China announced that starting } \\
\text { from June 1, 2019, it would increase the tax rate for } \\
\text { about } \$ 60 \text { billion goods which have already imposed } \\
\text { additional tariffs. }\end{array}$ \\
\hline $\begin{array}{l}\text { 6. As of October } 1,2019 \text {, the USA has published } \\
\text { eight batches of exclusion lists for imports from } \\
\text { China, and no tariffs are imposed on the products in } \\
\text { the exclusion lists. }\end{array}$ & $\begin{array}{l}\text { 6. On August 23, 2019, China announced that it } \\
\text { would impose additional } 10 \% \text { and } 5 \% \text { tariffs on } \\
\text { approximately } \$ 75 \text { billion of imported goods from } \\
\text { the USA, which will be implemented in two batches } \\
\text { from September 1st and December } 15 \text { th, } 2019 \text {. }\end{array}$ \\
\hline & $\begin{array}{c}\text { 7. On August 23, 2019, China announced that from } \\
\text { December 15, 2019, it would resume imposing } 25 \% \\
\text { and 5\% tariffs on automobiles and parts originating } \\
\text { in the USA. }\end{array}$ \\
\hline & $\begin{array}{l}\text { 8. Until October } 1,2019 \text {, China has announced a } \\
\text { batch of exclusion lists for imports from the USA, } \\
\text { and no tariffs will be imposed on products in the } \\
\text { exclusion list. }\end{array}$ \\
\hline
\end{tabular}

From the process of Sino-US imposing tariffs on each other, we can see it is clear that they have interacted with each other in their trade strategies. The trade negotiations between China and the USA will not be completed overnight, nor will reach a mutually satisfactory agreement in the short term. The two sides often negotiate and tariff wars still often occur. It needs a relatively long time to achieve a stable and balanced state of strategies. Analyzing the process of Sino-US trade friction, we can see that the strategies of China and the USA in trade friction have noticeable characteristics of the evolutionary game. The first is the assumption of bounded rationality in the game process. Both China and the USA are world powers, and any decisions and actions made by them will have a significant impact on the two countries, even on the world. They cannot respond to each other's actions optimally and it is impossible to obtain the best result instantly in the strategy game. The second is the incomplete information in-game process. Due to historical traditions, ideologies, and other factors, the gap between China and the USA has led to an inability to fully understand each other's strategic ideas and behaviors. During the game,

ISSN: 0010-8189

(c) CONVERTER 2020

www.converter-magazine.info 
both two sides need to find strategies to be adapted to each other based on limited information. Therefore, this paper adopts the evolutionary game model to analyze the strategic choice and evolution path of the two sides in the Sino-US trade friction and then helps predict future trend of the Sino-US trade friction and give a reasonable solution.

\subsection{Evolutionary game analysis of the Sino-US trade war}

4.2.1. Evolutionary game basic assumptions of the model

Hypothesis 1: China and the USA are main players in the evolutionary game. Under the assumption of bounded rationality, due to differences in economic strength, national interests, and strategic goals between China and the USA. Their choices of game strategies in the trade war are also inconsistent, and the optimal strategy and the equilibrium point of the Nash equilibrium cannot be reached at first. Therefore, during the trade war, China and the USA will constantly modify their own strategies, adjust their choices so that they can gradually achieve a stable and balanced combination of strategy.

Hypothesis 2: In the Sino-US trade war, both China and the USA can choose two strategies, cooperation (i.e., no tariffs) and competition (i.e., tariffs).

Hypothesis 3: Assuming that the probability of China choosing a cooperative strategy of no tax increase in trade friction is $p$, the probability of choosing a competitive strategy of tax increase is 1-p; correspondingly, suppose the probability of USA chooses a cooperative strategy is q, and the probability of choosing a competitive strategy is 1-q. Therefore, we can know that $\mathrm{p}, \mathrm{q} \in[0,1]$.

Hypothesis 4: Assuming that China and the USA impose tariffs on each other in a trade war, the benefits of adopting a competitive strategy are $\mathrm{T} 1$ and $\mathrm{T} 2$. If China and the USA do not choose to impose tariffs and adopt a cooperative strategy, the benefits that both parties can get are represented by P1 and P2.

Hypothesis 5: If China and the USA choose to mitigate trade conflicts and strengthen cooperation, a certain amount of upfront costs will need to be invested, such as communication costs for eliminating ideological differences, negotiation costs for trade negotiations, etc. In this article, we use $\mathrm{C} 1, \mathrm{C} 2$ to represent.

Hypothesis 6: In the Sino-US trade war, if one side chooses a cooperative strategy without increasing tariffs, but the other country chooses a competitive strategy to increase tariffs. Then the side that chooses a cooperative strategy will suffer huge losses, we use M1, M2 to represent this. The country abandons cooperation and chooses competitive strategy will get additional benefits, denoted by N1, N2. N1 and N2 are the speculative benefits of a country abandoning cooperation when another country chooses a cooperation strategy.

Based on the above assumptions, we can obtain the game matrix diagram of the strategic choices of China and the USA in the trade war, as shown in Table 3:

Table 3 The Game Matrix of Strategic Choice of Sino-US Trade War

\begin{tabular}{|c|c|c|c|}
\hline Country & \multicolumn{3}{|c|}{ USA } \\
\hline \multirow{3}{*}{ CHN } & Strategy & Cooperation ( q ) & Competition ( 1-q ) \\
\cline { 2 - 4 } & Cooperation ( p ) & $(\mathrm{T} 1+\mathrm{P} 1-\mathrm{C} 1, \mathrm{~T} 2+\mathrm{P} 2-\mathrm{C} 2)$ & $\begin{array}{c}\text { (T1-C1-M1, } \\
\text { T2+N2) }\end{array}$ \\
\cline { 2 - 4 } & Competition (1-p ) & $(\mathrm{T} 1+\mathrm{N} 1, \mathrm{~T} 2-\mathrm{C} 2-\mathrm{M} 2)$ & $(\mathrm{T} 1, \mathrm{~T} 2)$ \\
\hline
\end{tabular}

4.2.2 Model construction and derivation of dynamic evolutionary game

In the Sino-US trade war, when China chooses a cooperative strategy, the expected benefit will be:

ISSN: 0010-8189

(c) CONVERTER 2020

www.converter-magazine.info 
Volume 2021, No. 3

$E_{C H N, \text { Cooperation }}=q\left(T_{1}+P_{1}-C_{1}\right)+(1-q)\left(T_{1}-C_{1}-M_{1}\right)$; When China chooses the competitive strategy, the expected benefits will be: $E_{C H N, \text { Competition }}=q\left(T_{1}+N_{1}\right)+(1-q) T_{1}$. In this regard, when China adopts a mixed strategy, the expected benefit will be: $E_{C H N}=p E_{C H N, \text { Cooperation }}+(1-p) E_{C H N, \text { Competition }}$. When the USA chooses a cooperative strategy, the expected benefits it will be: $E_{\text {USA,Cooperation }}=p\left(T_{2}+P_{2}-C_{2}\right)+(1-p)\left(T_{2}-C_{2}-M_{2}\right)$; When the USA chooses the competitive strategy, the expected benefits will be: $E_{U S A, \text { Competition }}=p\left(T_{2}+N_{2}\right)+(1-p) T_{2}$. When the USA adopts a mixed strategy, the expected benefit will be: $E_{U S A}=q E_{U S A, \text { Cooperation }}+(1-q) E_{U S A, \text { Competition }}$.

According to the expected return value of the mixed strategies of China and the USA under different probabilities. Referring to the practices of Taylor (1978) [26], the dynamic equations of replication between China and the USA under different strategies can be obtained respectively. The replication dynamic equation of China's cooperation strategy is shown in formula (1):

$$
\begin{aligned}
f(p) & =d p / d t=p\left(E_{C H N, \text { Cooperation }}-E_{C H N}\right) \\
& =p(1-p)\left(E_{C H N, \text { Cooperation }}-E_{C H N, \text { Competition }}\right) \\
& =p(1-p)\left[q\left(P_{1}+M_{1}-N_{1}\right)-C_{1}-M_{1}\right]
\end{aligned}
$$

The dynamic equation of replication obtained by the USA adopting a cooperative strategy is shown in formula (2):

$$
\begin{aligned}
& f(q)=d q / d t=q\left(E_{U S A, \text { Cooperation }}-E_{U S A}\right) \\
& =q(1-q)\left(E_{U S A, \text { Cooperation }}-E_{U S A, \text { Competition }}\right) \\
& =q(1-q)\left[p\left(P_{2}+M_{2}-N_{2}\right)-C_{2}-M_{2}\right]
\end{aligned}
$$

On the replication dynamic equations (1) and (2) obtained by the cooperation strategy between China and the USA. We combined the replication dynamic equations to analyze the equilibrium of the evolutionary game, and further discuss the stability of the equilibrium point.

$$
\left\{\begin{array}{l}
f(p)=p(1-p)\left[q\left(P_{1}+M_{1}-N_{1}\right)-C_{1}-M_{1}\right] \\
f(q)=q(1-q)\left[p\left(P_{2}+M_{2}-N_{2}\right)-C_{2}-M_{2}\right]
\end{array}\right.
$$

We set the equation $f(p)=f(q)=0$, then $(p, q)$ can get 5 possible game equilibrium points, which are respectively $S_{1}(0,0), S_{2}(0,1), S_{3}(1,0), S_{4}(1,1), S_{5}\left(p^{*}, q^{*}\right)$. Among this, $p^{*}=\frac{C_{2}+M_{2}}{P_{2}+M_{2}-N_{2}}, q^{*}=\frac{C_{1}+M_{1}}{P_{1}+M_{1}-N_{1}}$.

\subsubsection{Game equilibrium point stability analysis of Sino-US Trade War}

We use the local stability analysis in the Jacobian matrix to explore the characteristics of the equilibrium point's stability of the two-party strategy game in the Sino-US trade friction. According to the copy of dynamic simultaneous equation (3), the Jacobian matrix is obtained by solving the partial derivatives of $p$ and $q$, as showed in the formula (4):

ISSN: 0010-8189

(c) CONVERTER 2020 


$$
\begin{aligned}
& J=\left(\begin{array}{l}
\frac{d f(p)}{d p}, \frac{d f(p)}{d q} \\
\frac{d f(q)}{d p}, \frac{d f(q)}{d q}
\end{array}\right) \\
& =\left(\begin{array}{l}
(1-2 p)\left[q\left(P_{1}+M_{1}-N_{1}\right)-C_{1}-M_{1}\right], p(1-p)\left(P_{1}+M_{1}-N_{1}\right) \\
q(1-q)\left(P_{2}+M_{2}-N_{2}\right),(1-2 q)\left[p\left(P_{2}+M_{2}-N_{2}\right)-C_{2}-M_{2}\right]
\end{array}\right)
\end{aligned}
$$

According to the Jacobian matrix parameter in the formula (4), combined with the game matrix in table 3 , this article would be divided into the following categories to discuss, and then obtain the stability characteristics of the equilibrium point.

Situation 1: In the Sino-US trade friction, the net benefits that China or the USA can obtain by adopting cooperation strategies exceed the speculative benefits which can be obtained when one side chooses the cooperation strategy and the other side adopts the competitive strategy. Among them, net benefits are the benefits obtained by the cooperation minus the initial cost required for the cooperation. As showed in the formula (5):

$$
\left\{\begin{array}{l}
P_{1}-C_{1}>N_{1} \\
P_{2}-C_{2}>N_{2}
\end{array}\right.
$$

In this case there is $p^{*} \in(0,1), q^{*} \in(0,1)$, following partial equilibrium point evolutionary game system: $S_{1}(0,0)$, $S_{2}(0,1), S_{3}(1,0), S_{4}(1,1), S_{5}\left(p^{*}, q^{*}\right)$. Substitute these local equilibrium points into the Jacobian matrix, and solve the value and trace of its determinant. When the matrix determinant is positive and the trace is negative, the local equilibrium point is stable in the evolutionary game system. When the value and trace of the calculated determinant are both greater than 0 , the local equilibrium point of the evolutionary game system is unstable. When the determinant is negative and the trace is uncertain, the local equilibrium point is a saddle point. The calculation results are shown in Table 4:

Table4 The equilibrium points of the evolutionary game of Sino-US trade friction in Situation1

\begin{tabular}{|c|c|c|c|c|c|}
\hline $\begin{array}{c}\text { Equilibrium } \\
\text { point }\end{array}$ & The value of the matrix & $\begin{array}{c}\text { Symb } \\
\text { ol }\end{array}$ & Matrix trace & $\begin{array}{c}\text { Symb } \\
\text { ol }\end{array}$ & Stability \\
\hline$S_{1}(0,0)$ & $\left(C_{1}+M_{1}\right)\left(C_{2}+M_{2}\right)$ & + & $-\left(C_{1}+M_{1}\right)-\left(C_{2}+M_{2}\right)$ & - & ESS \\
\hline$S_{2}(0,1)$ & $\left(P_{1}-N_{1}-C_{1}\right)\left(C_{2}+M_{2}\right)$ & + & $\left(P_{1}-N_{1}-C_{1}\right)+\left(C_{2}+M_{2}\right)$ & + & Unstable \\
\hline$S_{3}(1,0)$ & $\left(C_{1}+M_{1}\right)\left(P_{2}-N_{2}-C_{2}\right)$ & + & $\left(C_{1}+M_{1}\right)+\left(P_{2}-N_{2}-C_{2}\right)$ & + & Unstable \\
\hline$S_{4}(1,1)$ & $\left(P_{1}-N_{1}-C_{1}\right)\left(P_{2}-N_{2}-C_{2}\right)$ & + & $-\left(P_{1}-N_{1}-C_{1}\right)-\left(P_{2}-N_{2}-C_{2}\right)$ & - & ESS \\
\hline$S_{5}\left(p^{*}, q^{*}\right)$ & $-\frac{\left(C_{1}+M_{1}\right)\left(P_{1}-N_{1}-C_{1}\right)\left(C_{2}+M_{2}\right)\left(P_{2}-N_{2}-C_{2}\right)}{\left(P_{1}+M_{1}-N_{1}\right)\left(P_{2}+M_{2}-N_{2}\right)}$ & - & 0 & 0 & $\begin{array}{c}\text { Saddle } \\
\text { point }\end{array}$ \\
\hline
\end{tabular}

It can be seen from Table 4 that in the Sino-US trade friction, the evolutionary game system of strategic choice has two stable equilibrium points, $S_{1}(0,0)$ and $S_{4}(1,1)$, and the corresponding strategy choices are (competition, competition), (cooperation, cooperation), This shows that in the Sino-US trade friction, when the evolutionary game system is in a stable state, both China and the USA will choose cooperation or competition strategies at the same time. That is, one side adopts an increase in tariffs and the other side will also adopt retaliatory measures that increase tariffs. The dynamic evolution path is shown in Figure 3:

ISSN: 0010-8189 


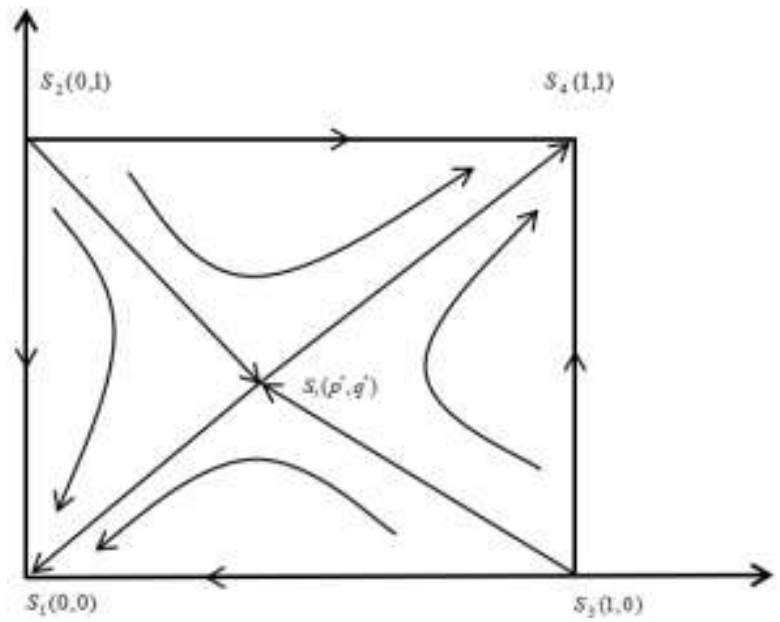

Fig 3 The dynamic evolution path of the strategic choices in Situation 1

Situation 2: In the Sino-US trade friction, the net benefits that China or the USA can obtain by adopting a cooperative strategy is less than the speculative benefits that can be obtained when one side chooses a cooperative strategy but the other side adopts a competitive strategy. As shown in formula (6):

$$
\left\{\begin{array}{l}
P_{1}-C_{1} \leq N_{1} \\
P_{2}-C_{2} \leq N_{2}
\end{array}\right.
$$

From (6) we can know $p^{*} \geq 1$ and $q^{*} \geq 1$. In such condition, the evolutionary game system has only four partial equilibrium point, $S_{1}(0,0), S_{2}(0,1), S_{3}(1,0), S_{4}(1,1)$. Substituted into the matrix determinant and trace, we can obtain stability characteristics in this situation, as shown in Table 5: There is only one stable equilibrium point in the evolutionary game system of Sino-US trade friction strategy selection, that is $S_{1}(0,0)$, and the corresponding strategy selection is (competition, competition). It shows that under the conditions of situation 2, when the evolutionary game system of strategic choice reaches a stable equilibrium state, both China and the USA will eventually adopt a competitive strategy in the trade friction, which may be manifested that China and the USA impose tariffs on each other or they may take other more intense competition measures. The dynamic evolution path of the trade strategy selection in the situation2 is shown in Figure 4:

Table 5 The equilibrium points of the evolutionary game of Sino-US trade friction in Situation2

\begin{tabular}{|c|c|c|c|c|c|}
\hline $\begin{array}{c}\text { Equilibrium } \\
\text { point }\end{array}$ & The value of the matrix & $\begin{array}{c}\text { Symb } \\
\text { ol }\end{array}$ & Matrix trace & Symbol & Stability \\
\hline$S_{1}(0,0)$ & $\left(C_{1}+M_{1}\right)\left(C_{2}+M_{2}\right)$ & + & $-\left(C_{1}+M_{1}\right)-\left(C_{2}+M_{2}\right)$ & - & ESS \\
\hline$S_{2}(0,1)$ & $\left(P_{1}-N_{1}-C_{1}\right)\left(C_{2}+M_{2}\right)$ & - & $\left(P_{1}-N_{1}-C_{1}\right)+\left(C_{2}+M_{2}\right)$ & $\begin{array}{c}\text { uncertai } \\
\mathrm{n}\end{array}$ & $\begin{array}{c}\text { Saddle } \\
\text { point }\end{array}$ \\
\hline$S_{3}(1,0)$ & $\left(C_{1}+M_{1}\right)\left(P_{2}-N_{2}-C_{2}\right)$ & - & $\left(C_{1}+M_{1}\right)+\left(P_{2}-N_{2}-C_{2}\right)$ & $\begin{array}{c}\text { uncertai } \\
\mathrm{n}\end{array}$ & $\begin{array}{c}\text { Saddle } \\
\text { point }\end{array}$ \\
\hline$S_{4}(1,1)$ & $\left(P_{1}-N_{1}-C_{1}\right)\left(P_{2}-N_{2}-C_{2}\right)$ & + & $-\left(P_{1}-N_{1}-C_{1}\right)-\left(P_{2}-N_{2}-C_{2}\right)$ & + & Unstable \\
\hline
\end{tabular}

ISSN: 0010-8189

(c) CONVERTER 2020 


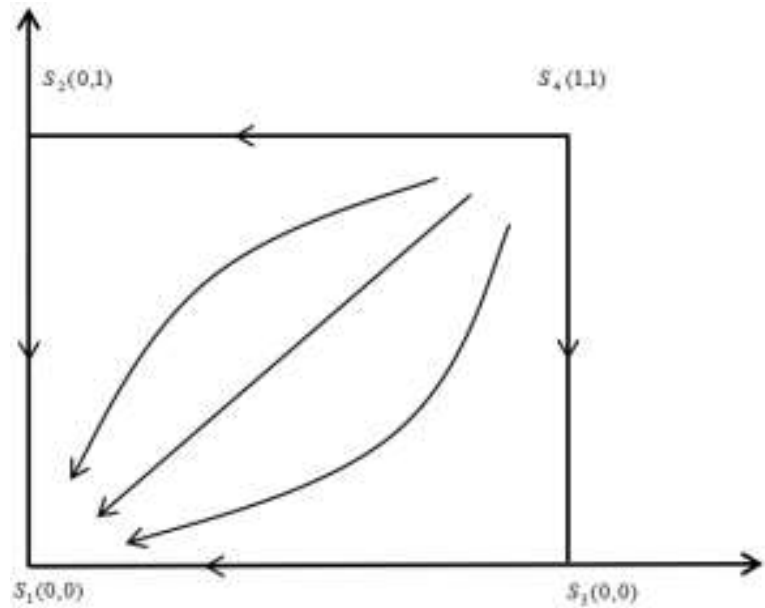

Fig 4 The dynamic evolution path of the strategic choices in Situation 2

Situation 3: In the Sino-US trade friction, only one side of China or the USA can obtain net benefits by adopting a cooperative strategy than the speculative benefits when one side chooses a cooperative strategy and another side adopts a competitive strategy. As shown in formula (7):

$$
\left\{\begin{array}{l}
P_{1}-C_{1}>N_{1} \\
P_{2}-C_{2}<N_{2}
\end{array},\left\{\begin{array}{l}
P_{1}-C_{1}<N_{1} \\
P_{2}-C_{2}>N_{2}
\end{array}\right.\right.
$$

Take China's net benefits greater than speculative income as an example. There is $p^{*}>1, q^{*}<1$. In this case, the evolutionary game system of Sino-US trade friction has only 4 partial equilibrium points, that is $S_{1}(0,0), S_{2}(0,1)$, $S_{3}(1,0), S_{4}(1,1)$, Substitute into the matrix determinant and trace to obtain the stability characteristics in situation 3 , as shown in Table 6:

Table 6 The equilibrium points of the evolutionary game of Sino-US trade friction in Situation3

\begin{tabular}{|c|c|c|c|c|c|}
\hline $\begin{array}{c}\text { Equilibrium } \\
\text { point }\end{array}$ & The value of the matrix & $\begin{array}{c}\text { Symb } \\
\text { ol }\end{array}$ & Matrix trace & Symbol & Stability \\
\hline$S_{1}(0,0)$ & $\left(C_{1}+M_{1}\right)\left(C_{2}+M_{2}\right)$ & + & $-\left(C_{1}+M_{1}\right)-\left(C_{2}+M_{2}\right)$ & - & ESS \\
\hline$S_{2}(0,1)$ & $\left(P_{1}-N_{1}-C_{1}\right)\left(C_{2}+M_{2}\right)$ & + & $\left(P_{1}-N_{1}-C_{1}\right)+\left(C_{2}+M_{2}\right)$ & + & uncertain \\
\hline$S_{3}(1,0)$ & $\left(C_{1}+M_{1}\right)\left(P_{2}-N_{2}-C_{2}\right)$ & - & $\left(C_{1}+M_{1}\right)+\left(P_{2}-N_{2}-C_{2}\right)$ & $\begin{array}{c}\text { uncertai } \\
\mathrm{n}\end{array}$ & $\begin{array}{c}\text { Saddle } \\
\text { point }\end{array}$ \\
\hline$S_{4}(1,1)$ & $\left(P_{1}-N_{1}-C_{1}\right)\left(P_{2}-N_{2}-C_{2}\right)$ & - & $-\left(P_{1}-N_{1}-C_{1}\right)-\left(P_{2}-N_{2}-C_{2}\right)$ & $\begin{array}{c}\text { uncertai } \\
\mathrm{n}\end{array}$ & $\begin{array}{c}\text { Saddle } \\
\text { point }\end{array}$ \\
\hline
\end{tabular}

From Table 6, we can see that under the conditions of situation 3, there is only one stable equilibrium point in the evolutionary game system of Sino-US trade friction strategy selection, that is $S_{1}(0,0)$. When the net benefits of one country adopting a cooperative strategy is greater than the speculative benefits, but the net benefits of another country adopting cooperative strategy is less than the speculative benefits. The latter will abandon the cooperation strategy and adopt competitive strategy, and the former will also be forced to change from cooperative strategy to competitive strategy to avoid greater losses. When the evolutionary game system of strategic choice reaches a stable equilibrium state, both China and the USA will eventually adopt competitive strategy in trade friction, that is imposing tariffs on each other and other targeted radical measures. Figure 5 shows the dynamic evolution path of trade strategy selection under situation 3:

ISSN: 0010-8189

(c) CONVERTER 2020

www.converter-magazine.info 


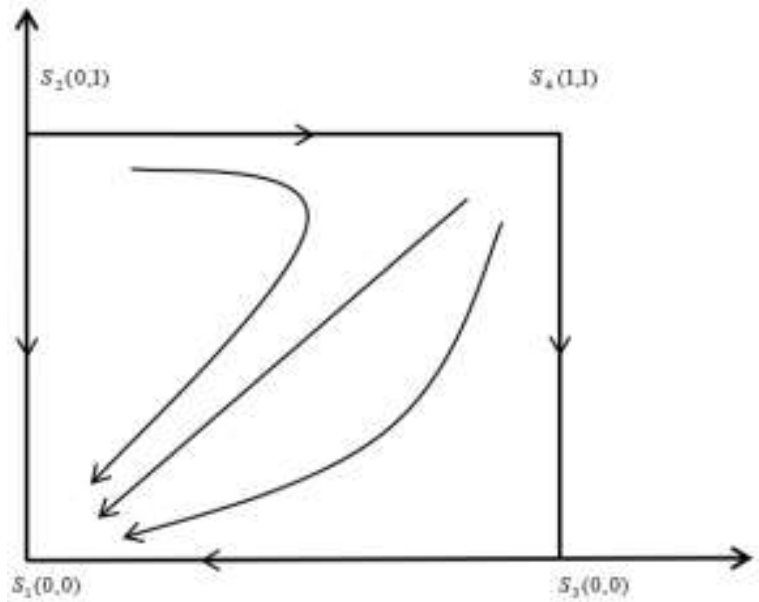

Fig 5 The dynamic evolution path of Sino-US trade strategy choices in Situation3

To sum up, in situation 2 and 3, as long as the net benefits obtained by one side adopting cooperative strategy is less than the speculative benefits obtained by adopting competitive strategy. There is only one stable point in the evolutionary game system $S_{1}(0,0)$, the corresponding strategy choice is (competition, competition). Both China and the USA tend to adopt competitive strategies and impose tariffs on each other. While in situation 1, the evolutionary game system has two stable points $S_{1}(0,0)$ and $S_{4}(1,1)$, and the corresponding strategy choices are (competition, competition) and (cooperation, cooperation). The equilibrium point of the evolutionary game system of Sino-US trade friction will depend on the initial state of the game between China and the USA, because $S_{5}\left(p^{*}, q^{*}\right)$ is a saddle point. The two regions $S_{5} S_{3} S_{1} S_{2}$ and $S_{5} S_{3} S_{4} S_{2}$ composed of $S_{1}(0,0), S_{2}(0,1), S_{3}(1,0), S_{4}(1,1)$, $S_{5}\left(p^{*}, q^{*}\right)$. When the initial state of China and the USA is in the $S_{5} S_{3} S_{1} S_{2}$, the evolutionary game system will converge to $S_{1}(0,0)$, (competition, competition) is the only stable state of equilibrium between the two sides in the Sino-US trade friction. When the initial state of China and the USA is in the $S_{5} S_{3} S_{4} S_{2}$, the evolutionary game system will converge to $S_{4}(1,1)$, (cooperation, cooperation) is the only stable state of equilibrium between the two sides in the Sino-US trade friction.

It can be seen from this that whether China and the USA can cooperate in trade friction depends on whether they meet the situation 1 . The net benefits that China and the USA can obtain by adopting cooperation strategies exceed the speculative benefits that can be obtained when the one side chooses a cooperation strategy and another side adopts a competitive strategy. Secondly, it will depend on the initial state of the evolutionary game of trade friction between China and the USA. When the area of the $S_{5} S_{3} S_{1} S_{2}$ is larger than the $S_{5} S_{3} S_{4} S_{2}$, the initial state is more likely to fall at $S_{5} S_{3} S_{1} S_{2}$ and the probability of choosing (competition, competition) strategy combination is higher. When the area of $S_{5} S_{3} S_{1} S_{2}$ increases and the area of $S_{5} S_{3} S_{4} S_{2}$ decreases, it indicates that the probability of choosing (competition, competition) strategy combination increases, while the probability of choosing (cooperation, cooperation) strategy combination decreases. The area of the $S_{5} S_{3} S_{1} S_{2}$ region can be calculated from Figure 3, as shown in formulas (8)-(9):

$$
\pi_{S_{5} S_{3} S_{1} S_{2}}=\frac{1}{2} \times 1 \times p^{*}+\frac{1}{2} \times 1 \times q^{*}=\frac{1}{2}\left(\frac{C_{2}+M_{2}}{P_{2}+M_{2}-N_{2}}+\frac{C_{1}+M_{1}}{P_{1}+M_{1}-N_{1}}\right)
$$

And the area of $S_{5} S_{3} S_{4} S_{2}$ is:

ISSN: 0010-8189

(c) CONVERTER 2020

www.converter-magazine.info 


$$
\pi_{S_{5} S_{3} S_{4} S_{2}}=1-\pi_{S_{5} S_{3} S_{1} S_{2}}=1-\frac{1}{2}\left(\frac{C_{2}+M_{2}}{P_{2}+M_{2}-N_{2}}+\frac{C_{1}+M_{1}}{P_{1}+M_{1}-N_{1}}\right)
$$

In formula (8) and formula (9), the area of the $S_{5} S_{3} S_{1} S_{2}$ and $S_{5} S_{3} S_{4} S_{2}$ depends on the change direction of parameter values such as $P_{1}, P_{2}, C_{1}, C_{2}, M_{1}, M_{2}, N_{1}, N_{2}$ etc., which in turn affects the change of strategy combination in the evolutionary game.

Table 7 The Influence of Parameter Changes on the Direction of Game Strategy Selection

\begin{tabular}{|c|c|c|c|}
\hline Parameter change & The changes of $p^{*}, q^{*}$ & The changes of $\pi_{S_{5} S_{3} S_{1} S_{2}}$ & $\begin{array}{c}\text { Game Strategy } \\
\text { Selection }\end{array}$ \\
\hline$P_{1} \uparrow, P_{2} \uparrow$ & $p^{*} \downarrow, q^{*} \downarrow$ & $\pi_{S_{5} S_{3} S_{1} S_{2}} \downarrow$ & $\begin{array}{c}\text { (cooperation, } \\
\text { cooperation) }\end{array}$ \\
\hline$P_{1} \downarrow, P_{2} \downarrow$ & $p^{*} \uparrow, q^{*} \uparrow$ & $\pi_{S_{5} S_{3} S_{1} S_{2}} \uparrow$ & $\begin{array}{c}\text { (competition, } \\
\text { competition) }\end{array}$ \\
\hline$C_{1} \uparrow, C_{2} \uparrow$ & $p^{*} \uparrow, q^{*} \uparrow$ & $\pi_{S_{5} S_{3} S_{1} S_{2}} \uparrow$ & $\begin{array}{c}\text { (competition, } \\
\text { competition) }\end{array}$ \\
\hline$C_{1} \downarrow, C_{2} \downarrow$ & $p^{*} \downarrow, q^{*} \downarrow$ & $\pi_{S_{5} S_{3} S_{1} S_{2}} \downarrow$ & $\begin{array}{c}\text { (cooperation, } \\
\text { cooperation) }\end{array}$ \\
\hline$M_{1} \uparrow, M_{2} \uparrow$ & $p^{*} \uparrow, q^{*} \uparrow$ & $\pi_{S_{5} S_{3} S_{1} S_{2}} \uparrow$ & $\begin{array}{c}\text { (competition, } \\
\text { competition) }\end{array}$ \\
\hline$M_{1} \downarrow, M_{2} \downarrow$ & $p^{*} \downarrow, q^{*} \downarrow$ & $\pi_{S_{5} S_{3} S_{1} S_{2}} \downarrow$ & $\begin{array}{c}\text { (cooperation, } \\
\text { cooperation) }\end{array}$ \\
\hline$N_{1} \uparrow, N_{2} \uparrow$ & $p^{*} \uparrow, q^{*} \uparrow$ & $\pi_{S_{5} S_{3} S_{1} S_{2}} \uparrow$ & $\begin{array}{l}\text { (competition, } \\
\text { competition) }\end{array}$ \\
\hline$N_{1} \downarrow, N_{2} \downarrow$ & $p^{*} \downarrow, q^{*} \downarrow$ & $\pi_{S_{5} S_{3} S_{1} S_{2}} \downarrow$ & $\begin{array}{l}\text { (cooperation, } \\
\text { cooperation) }\end{array}$ \\
\hline
\end{tabular}

As can be seen from Table 7, in the Sino-US trade friction, the benefits $P_{1}$ and $P_{2}$ that the two sides can obtain from the cooperation strategy are inversely proportional to the area of $S_{5} S_{3} S_{1} S_{2}$. It shows that the more benefits that China and the USA obtain from choosing cooperation in trade friction, the greater possibility of choosing cooperation it will have, and vice versa. Cooperation costs $C_{1}, C_{2}$ are directly proportional to the area of $S_{5} S_{3} S_{1} S_{2}$, indicating that the greater differences between China and the USA in trade friction. There will be higher cooperation costs and greater the possibility of choosing competition. The losses $M_{1}, M_{2}$ and the speculative benefits $N_{1}, \quad N_{2}$ are directly proportional to the area of $S_{5} S_{3} S_{1} S_{2}$. It shows that in the Sino-US trade friction, the greater loss will be suffered when one side adopts competition and the other side chooses cooperation, or the higher speculative benefits from the other side adopts cooperation but another side chooses competition. China and the USA will unilaterally choose to change cooperation strategy, and then adopts competitive strategy. In the end, both China and the USA will choose a competitive strategy.

\section{Conclusions and Policy Recommendations}

The trade war initiated by the USA against China in 2018 reflects overall transformation of USA relations with China. The USA will continue to exert pressure on China through trade negotiations to force China to accept its terms and maintain leadership in the world. Both China and the USA will choose a dominant strategy in this trade friction, revise their own strategic choices and trade policies through continuous trade negotiations, and finally reach a stable equilibrium state. From the results of this article, we can find that as long as one of China and the USA adopts a cooperative strategy to obtain net benefits less than the speculative benefits obtained by adopting a competitive strategy, that is, when it is more advantageous to adopt a competitive strategy, both China and the USA will adopt a competitive strategy. The premise of the strategy for both countries to choose cooperation is the net benefits that China and the USA can obtain by adopting cooperation strategies exceed the speculative benefits ISSN: 0010-8189 
which can be obtained when one side chooses cooperation strategies but the other side adopts competitive strategies. Under this premise, the higher benefits of cooperation in the choice of trade strategy it is, the lower cost of cooperation, the lower loss of adhering to the cooperation strategy and the speculative benefits of abandoning cooperation it will be. There is a higher possibility that the two countries will eventually choose a strategic combination of cooperation. On the contrary, if the benefits of China and the USA in trade cooperation decrease, the cost of cooperation caused by ideological differences and strategic mistrust increases, the loss of sticking to cooperation or the speculative benefits of abandoning cooperation increase, China and the USA will eventually move towards a state of equilibrium (competition, competition), and all-round competition between China and the USA is inevitable.

China must consider how to properly deal its economic and trade relations with the world's largest power, the USA, balance the conflicts of interest between emerging powers and established powers, deepen the basis for cooperation between the two countries, and spare no effort to avoid the continuous trade friction with the USA. This paper puts forward following suggestions:

Firstly, China should strengthen trade negotiations with the USA, avoid the overall deterioration of relations between the two countries which may cause adverse international impact. As a responsible world power, China needs to play an exemplary role in safeguarding the world economic order and the overall situation of trade globalization, establish its image as a major power, and win more public support from all over the world. At the same time, China should maintain the existing multilateral trading system based on WTO rules, actively promote the reform of the WTO system and the continuous improvement of the trading system in the direction of openness, mutual benefit, and balance. To prevent western countries headed by the USA adopt unilateral trade protectionist measures, safeguard the legitimate economic and trade interests of developing countries.

Secondly, China should treat the changes in Sino-US relations correctly and safeguard the overall win-win cooperation between China and the USA. In this regard, China and the USA need to strengthen strategic dialogue, deepen cooperation, and give full play to their respective comparative advantages to achieve trade complementarity. China has increased its procurement of high-quality products and services from the USA, including agricultural products. The USA should liberalize barriers and restrictions on China's high-tech industries, adjusted the bilateral trade structure. Both China and the USA should properly resolve Sino-US trade friction, eliminate differences and misunderstandings in the economic and trade field, safeguard China's core interests and strategic bottom line, and promote the common development and prosperity of the Chinese and the USA's economies.

Thirdly, China should promote a new pattern of opening to the outside world and reduce the potential impact of China-US decoupling. In the Sino-US trade friction, China needs to make best preparation. It may face overall deterioration Sino-US relations and may decouple with the USA. In this regard, China should strengthen cooperation with developed countries such as the European Union, Japan and South Korea to partially replace the USA, and reduce dependence on the USA. On the other hand, China should speed up the construction of the "Belt and Road" trade and economy area, transferring China's investment and export channels, then building a new pattern of regional trade, and enhancing China's room for maneuver in the international. So as to offset the impact of Sino-US trade friction and even complete decoupling between China and the USA, and improve the security of China's economic and trade.

Finally, China should change its developing mode and enhance its inherent resilience of economic development. On the one hand, China should strengthen its innovation capabilities, master key technologies needed for development, promote its manufacturing level. On the other hand, China should improve the speed and intensity of upgrading and transformation of enterprises, and promote Chinese enterprises' status and role in the global value chains. In addition, China should promote the continuous upgrading of domestic consumption structure, stress the importance of domestic demand in economic development, and create an internal driving force for economic

ISSN: 0010-8189

(C) CONVERTER 2020

www.converter-magazine.info 
development.

\section{References}

[1] L. Liu, "Current international economic frictions and countermeasures facing China," Management World, no. 9, pp.73-80, 2004.

[2] C. H. Pei, "The development of my country's foreign trade: challenges, opportunities and countermeasures," Economic Research Journal, no. 9, pp. 103-112, 2005.

[3] Y. F. Wang, "The rise of great powers and international economic frictions-a discussion on Sino-US trade friction," Forum of World Economics \& Politics, no. 1, pp. 42-47, 2009.

[4] H. M. Huang, D. M. Fan, "Trade conflicts and strategic choices in the rise of great powers," Intertrade, no. 7, pp. 4-9, 2019.

[5] J. Y. Chen, "The background, causes, essence and Chinese countermeasures of the Sino-US trade war," Wuhan University Journal (Philosophy \& Social Science), vol. 71, no. 5, pp. 72-81, 2018.

[6] J. J. Liu, "The three-dimensional cause of the trump administration's trade war with China," Wuhan University Journal (Philosophy \& Social Science), vol. 71, no. 5, pp. 82-90, 2018.

[7] X. B. Wu, "Competition-oriented U.S. China policy and the transformation of Sino-U.S. relations," China International Studies, no. 4, pp. 14-31+2, 2019.

[8] D. K. Li, S. J. Hu, "Trump's tax reform and Sino-US trade friction," Economic Perspectives, no. 4, pp. 17-30, 2019.

[9] B. Li, C. M. Liu, "The causes and countermeasures of Sino-US economic and trade friction: Based on the perspective of trade expectations theory," Pacific Journal, no. 9, pp. 71-81, 2019.

[10] F. Yang, W. Y. Sun, Y. Cheng, "Does technology catch-up trigger Sino-US trade friction," China Industrial Economics, no. 10, pp. 99-117, 2018.

[11] Z. H. Wang, "Institutional recognition and economic and trade disputes - an analysis of the causes of the U.S. trade war with China," The Chinese journal of American studies, vol. 32, no. 5, pp. 49-65+6, 2018.

[12] M. E. Waugh, "International trade and income differences," American Economic Review, vol. 100, no. 5, pp. 2093-2124, 2010.

[13] C. D. Li, C. T. He, C. W. Lin, "Economic impacts of the possible China-US trade war," emerging markets finance and trade, vol. 54, no. 7, pp. 1557-1577, 2018.

[14] M. Amiti, S. J. Redding, D. E. Weinstein, "The Impact of the 2018 Tariffs on Prices and Welfare," Journal of Economic Perspectives, vol. 33, no. 4, pp. 187-210, 2019.

[15] L. G. Sheng, H. Y. Zhao, J. Zhao, "Why will Trump lose the trade war," China Economic Journal, vol. 12, no. 2, pp. 137-159, 2019.

[16] J. D., "Sachs Will America create a Cold War with China," China Economic Journal, vol. 12, no. 2, pp. 100-108, 2019.

[17] J. J. Hong, K. W. Li, "Reform and opening up and the global economy," Economic Perspectives, no.6, pp.100-111, 2019.

[18] Z. X. Luo, "The trump administration's reconstruction of Sino-US economic and trade relations: an investigation based on economic populism and economic nationalism," The Chinese Journal of American Studies, vol. 33, no. 5, pp. 76-102+7, 2019.

[19] T. T. Chong, X. Y. Li, "Understanding the China-US trade war: causes, economic impact, and the worst-case scenario," Economic and Political Studies, vol. 7, no. 2, pp. 185-202, 2019.

[20] C. H. Pei, B. Liu, "The kinetic energy conversion of China's foreign trade and the formation of new international competitive advantages," Economic Research Journal, vol. 54, no. 5, pp. 4-15, 2019.

[21] F. Feng, P. He, J. Han, "How can free trade agreements ease the dispute over rules in trade friction," China Industrial Economics, no. 10, pp. 118-136, 2018.

[22] M. J. Yu, R. Zhang, "Understanding the recent Sino-U.S. trade conflict," China Economic Journal, vol. 12, no. 2, pp. 160-174, 2019.

[23] J. H. Li, "The game mechanism and countermeasures of international trade friction," Frontiers, no. 16, ISSN: 0010-8189 
pp. 66-76, 2018.

[24] J. X. Wang, "Sino-US trade dispute response strategy and prospect prediction from the perspective of game theory," Finance \& Economics, no. 9, pp. 124-132, 2019.

[25] D. Xie, G. Zhang, "International trade and national conflict of interest: the multiple games of the Sino-US trade war and China's way out," China Review of Political Economy, vol. 10, no. 4, pp. 129-149, 2019.

[26] P. D. Taylor, L. B. Jonker, "Evolutionary stable strategies and game dynamics," Mathematical Biosciences, vol. 40, no. 1, pp. 145-156, 1978.

ISSN: 0010-8189

(c) CONVERTER 2020

www.converter-magazine.info 